\title{
SNOW ALBEDO REDUCTION IN CENTRAL ANDES BY ATMOSPHERIC AEROSOLS: CASE STUDY ON THE TUNUYÁN BASIN (ARGENTINA)
}

\author{
S. E. Puliafito ${ }^{1, *}$, T. Bolaño Ortiz ${ }^{1, *}$, R. Pascual ${ }^{1}$, A. Lopez-Noreña ${ }^{1}$, L. Berná $^{2}$ \\ ${ }^{1}$ Universidad Tecnológica Nacional / CONICET, Mendoza, Argentina \\ (epuliafito, tomas.bolano, romina.pascual, ana.lopez, lucas.berna)@frm.utn.edu.ar \\ ${ }^{2}$ Universidad Tecnológica Nacional / ANPCyT, Mendoza, Argentina
}

KEY WORDS: Snow albedo, MODIS, AOD, Snow Darkening Effect, WRF-Chem.

\begin{abstract}
:
Changes in snow albedo (SA) on several basins of the central Andes of Argentina are associated with the possible deposition of light-absorbing particles (LAP) in the austral spring. To demonstrate this possibility, we correlate SA with daily data of snow cover (SC), aerosol optical depth (AOD) and land surface temperature (LST) available from the Moderate-Resolution Imaging Spectroradiometer (MODIS) on board NASA Terra satellite during 2000-2016, and other derived parameters such as days after albedo (DAS) and snow precipitation (SP) from the Tropical Rainfall Measuring Mission (TRMM). We used satellite pixels with $100 \%$ snow cover to obtain monthly average value of SA, LST, AOD, DAS and SP performing multiple regression analysis. Further, we analysed biomass burning emissions in northern Argentina using MODIS products MCD64 collection C6 as possible source for snow pollution. Aerosol deposition and trajectories were analysed using WRF-Chem atmospheric numerical prediction model, with inventories of regional anthropogenic emissions of own elaboration (lat. $0.025^{\circ} \mathrm{x}$ long. $0.025^{\circ}$ ) and the estimation of open burning emissions from the FINN global inventory (Fire INventory from NCAR).
\end{abstract}

\section{INTRODUCTION}

Snow albedo is a parameter of great importance to determine the amount of solar radiation adsorbed in the cryosphere and is defined as a relationship between incoming and reflected solar radiation by a surface. Snow albedo variations are influenced, among others by the surface temperature, snowfall, snow age and snow impurities (Warren SG. et al. 1980; Levy RC. et al. 2007; Lee W. et al. 2012; Qian Y. et al. 2015).

Snow impurities (LAP) reduces the snow albedo and absorb more solar radiation (snow darkening effect - SDE), which further accelerates the snow aging process and the melting rate of the layer of snow (Clarke AD. et al. 1985; Hansen JE. et al 1997; Hansen JE. et al. 2001; Menon S. 2002; Pepin N. et al. 2015). LAP and its SDE were identified as the main forcing agents that affect climate change (Griggs DJ. et al. 2002; IPCC 2007).

Estimating the snow darkening effect (SDE) through the presence of snow impurities requires a great effort of in situ measurements covering large snowy areas in many cases hardly accessible. Therefore, retrieved satellite remote sensing data are a good alternative to analyse data with acceptable spatial and temporal distribution covering large regions.

In the Central Andes, satellite products [mainly Moderate Resolution Imaging Spectroradiometer (MODIS)] have also been used to analyse the snow cover in the Mendoza River Basin (Argentine eastern slope of Central Andes) (Cara L. et al. 2016). Recently, it was established that the cover, albedo and duration of snow decreased by $13.4 \pm 4 \%, 7.4 \pm 2 \%$ and $43 \pm 20$ days, respectively (Malmros JK et al. 2018). A case study in the area of the sky complex in Portillo $\left(32.83^{\circ} \mathrm{S}, 70.13^{\circ} \mathrm{W}\right)$ showed a negative relationship between local vehicle emissions and the snow albedo measured in situ. However, it could not quantify the SDE from vehicular emissions (Cereceda-Balic F. et al. 2018).

The main objective of this study was to investigate the aerosols effect on the snow albedo reduction in Central Andes of
Argentina (CAA) during the spring season, based on satellite remote sensing data for the years 2000-2016. The role that aerosols play in the negative trend of snow albedo (Malmros JK. et al. 2018), and their relationship with the distribution and local deposition of aerosols in snow has been identified in previous studies for this region (Cereceda-Balic et al. 2012; Bolaño-Ortiz et al. 2017; Cereceda-Balic et al. 2018; BolañoOrtiz et al. 2018).

\section{DATA AND METHODOLOGY}

We selected the Tunuyán basin (Tyn) of Central Andes of Argentina to analyse the reduction of albedo in the CAA as shown in Figure 1.

The Global Digital Elevation Model (GTOPO30) developed by the Data Center of the National Center for Earth Observation and Science (EROS) of the United States Geological Survey (USGS) was used as a surface topography ((https://www.usgs.gov/centers/eros/science/usgs-eros-archivedigital-elevation-global-30-arc-second-elevation-gtopo30).

Daily satellite data of snow cover (SC), snow albedo (SA), land surface temperature (LST), optical aerosol depth (AOD) and precipitation (P) were analysed (Table 1). SC and SA were recovered from MODIS images (Klein AG et al. 2002; Hall DK et al. 2002; Riggs GA et al. 2006). MODIS products consider slopes and snow cover on mountainous surfaces (Klein AG. et al. 2002; Pu Z et al. 2007).

\begin{tabular}{|c|c|c|c|}
\hline Parameter & $\begin{array}{l}\text { Satellite } \\
\text { product }\end{array}$ & $\begin{array}{c}\text { Spatial } \\
\text { resolution } \\
(\mathrm{km})\end{array}$ & Pixels \\
\hline $\mathrm{SC}$ & MOD 10 & 0.5 & $100 \%$ \\
\hline SA & MOD 10 & 0.5 & \multirow{4}{*}{$\begin{array}{c}\text { All pixels } \\
\text { with } 100 \% \\
\text { snow cover }\end{array}$} \\
\hline LST & MOD 11 & 1 & \\
\hline AOD & MOD 04 & 10 & \\
\hline $\mathrm{P}$ & $3 \mathrm{~B} 42$ & 25 & \\
\hline
\end{tabular}

Table 1. Satellite products used

\footnotetext{
* Corresponding author
} 


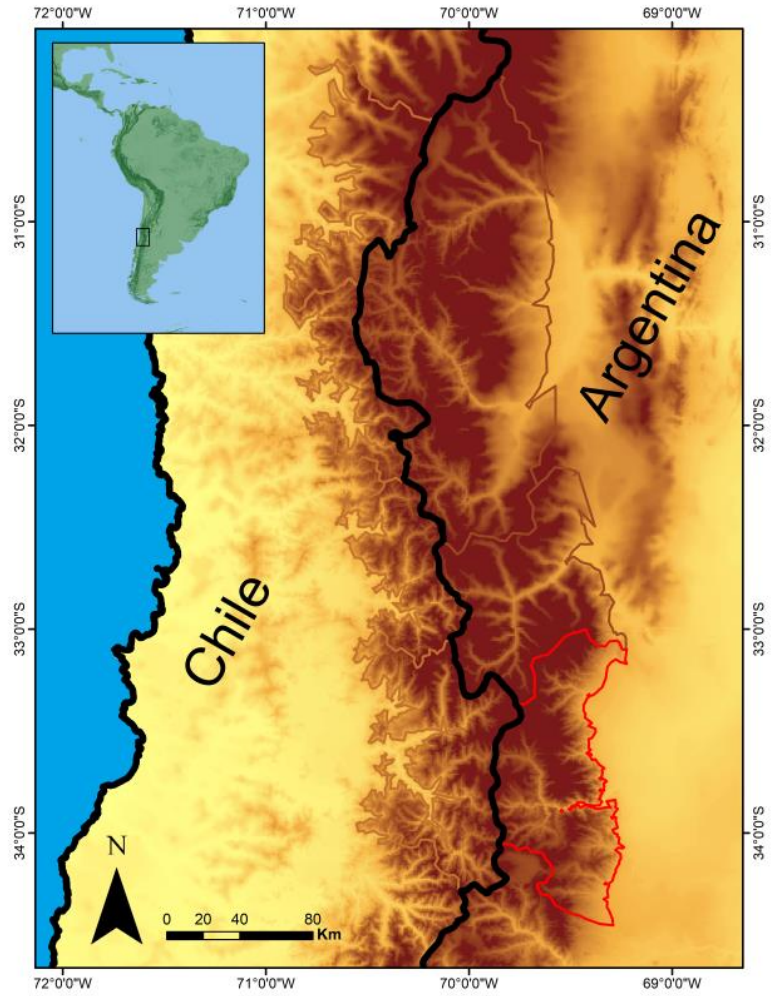

Figure 1. Study area in South America and the Central Andes. Red line encloses the Tunuyán basin on the eastern side of the Andes mountain of CAA.

The LST product used (Wan Z. et al 1997; Pepin N. et al. 2015) has been shown to be suitable for mountainous areas with an agreement of $86 \%$ (Klein AG. et al 2003). The AOD aerosol product was recovered from MOD04 (Levy R. et al 2015) with a wavelength of $0.55 \mu \mathrm{m}$, where snow albedo showed the greatest variability due to light absorbing particles (Qian Y et al 2015; Cereceda-Balic et al. 2018; Skiles SMK et al. 2018) Precipitation was obtained from the Tropical Rain Measurement Mission (TRMM) (Adler RF et al 2000; Huffman GJ et al. 2007a; Huffman GJ et al 2007b) that provided spatial information and vertical precipitation profiles (Hong $\mathrm{Y}$ et al. 2006).

The presence of clouds frequently produced missing satellite data (daily), to minimize the gaps and produce a more reliable statistic we worked with a 17 -year series of daily data from the southern spring (September to November 2000 to 2016).

Since TRMM detects only liquid precipitation, a parameter was generated to estimate the days where precipitation was snow (SP), by detecting temperatures below the freezing level at -4 ${ }^{\circ} \mathrm{C}$, taking the uncertainties of MOD11 measurements into account (Seemann SW et al 2006). The number of days between snowfalls was also estimated by another parameter: days after snow (DAS).

To estimate the effect of aerosol deposition on the SA reduction in each basin, the correlation of SA to LST, AOD, snow precipitation (SP) and DAS was investigated by means of a multiple regression analysis for all available data sets.

Finally, the Weather Research and Forecasting with Chemistry (WRF-Chem) numerical prediction model (Flanner MG et al 2007) was run for selected days and we compared them with the average snow albedo (SA) and the AOD data recovered in the basin. To estimate the regional source of black carbon (BC), we studied the winds that drag air masses toward the high areas of the basin studied using WRF-Chem and backward trajectories using NOAA HYSPLIT (Stein AF et al. 2015; Rolph G et al. 2017).

\section{ANALYSIS AND DISCUSSION}

\subsection{Observational data}

Table 2 shows the linear correlation $r$ among all the variables. It is observed that the LST, ODA, and DAS contribute negatively to the SA, while the SP increases the SA. This can also be seen in the $\mathrm{r}$ of -0.6487 , which correlates SP and LST, which means that when the snow increases, the surface temperature decreases.

\begin{tabular}{|c|c|c|c|c|c|}
\hline & SA & LST & AOD & SP & DAS \\
\hline SA & 1 & & & & \\
\hline LST & -0.8565 & 1 & & & \\
\hline AOD & 0.1705 & -0.2165 & 1 & & \\
\hline SP & 0.5881 & -0.6487 & 0.1019 & 1 & \\
\hline DAS & -0.4146 & 0.5863 & -0.2097 & -0.2165 & 1 \\
\hline
\end{tabular}

Table 2. Correlation coefficient between all variables

To analyse the relationship between SA and LST, AOD, DAS and SP, we calculated the correlation coefficients (r) using their monthly averages from September to November during 20002016, as shown in Table 3. These correlations show that the LST has the greatest impact on the SA. Furthermore, the sign coincides with the expected effect on the snow albedo: SA decreases with LST, AOD, DAS and increases with the SP (Grell GA et al 2005; Flanner MG et al 2006; Qian Y et al 2015; Skiles SMK et al 2018).

\begin{tabular}{|c|c|c|c|c|}
\hline Cuenca & LST & AOD & SP & DAS \\
\hline Tyn & -0679 & -0.388 & 0.337 & -0.280 \\
\hline
\end{tabular}

Table 3. Correlation coefficient $r$ with SA

The correlation coefficients analysis (r) shows that LST, AOD, DAS and SP are not linearly independent. However, sometimes the relationship is not linear using only one parameter. Therefore, we utilized a multiple linear regression technique to evaluate the AOD impact on the SA decrease (Lee $\mathrm{W}$ et al 2012). We used a multiple linear regression technique, standardizing the data with its standard deviations, for the austral spring months (2000-2016) for each parameter obtaining the following relation: (shown in Eq. 1). Confidence Level: $95 \%$

$\mathrm{SA}=-0.019 \times 10^{-16}-0.596 \mathrm{LST}-0.143 \mathrm{AOD}+0.161 \mathrm{SP}-$

0.013DAS $\quad \mathrm{R}^{2}=0.62$

The Eq. 1 show that a larger LST, AOD and DAS lead to a lower surface albedo (SA), which coincides with the physical behaviour of melting snow. When surface temperature (LST) increases, it also increases the snow grains. Impurities on the snow increase the absorbed radiation, and since older snow is darker, this leads to a lower SA

To estimate the LST, AOD, PS and DAS contributions to the behaviour of SA, we used the difference of the normalized mean values of LST, AOD, DAS and SP for the spring months (September to November, years 2001-2016). Table 4 shows the contribution percentage of each parameter to SA. 


\begin{tabular}{|c|c|c|c|c|}
\hline Cuenca & \%LST & \%AOD & SP & \%DAS \\
\hline Tyn & 89.1 & 8.58 & 2.29 & 0.02 \\
\hline
\end{tabular}

Table 4. Contribution percentage to SA of each parameter for the data sets and basins analysed using the multiple regression model

The multiple regression model predicts that the AOD is the second parameter that most contributes to SA decrease after LST. AOD and SP have a significant contribution to the SA of the study area $(8.58 \%$ and $2.29 \%$ respectively).

\subsection{Case study using WRF-Chem model}

Temporal distribution observed on the Tunuyan basin from September 26 to 30, 2016, shows that with a 1-day AOD delay over the SA (Figure. 2), the expected behaviour of the AOD over the SA coincides with what is expected intuitively and predicted by the multiple regression model. We consider that the 1-day delay of AOD with respect to the SA is a consequence of transport time and deposition rate ( $\mathrm{Xu} \mathrm{R}$ et al 2018). Moreover, the measuring satellite passes by the study area early on the day, and, therefore, the effect of the aerosol deposited would occur in the course of the day when the snow cover receives radiation from the sun. For the particular analysed days, the sunrise and sunset were at 6:24 and 18:44 local time, respectively (i.e., $12.3 \mathrm{~h}$ of solar irradiation). However, the satellite that captured the AOD measurement passed at 10:45 and 9:45 local time on September 28 and 29, respectively; therefore, the effect of the measured AOD on the SA (during the rest of the solar day: 8 and $9 \mathrm{~h}$, respectively) will be better observed on the next day.

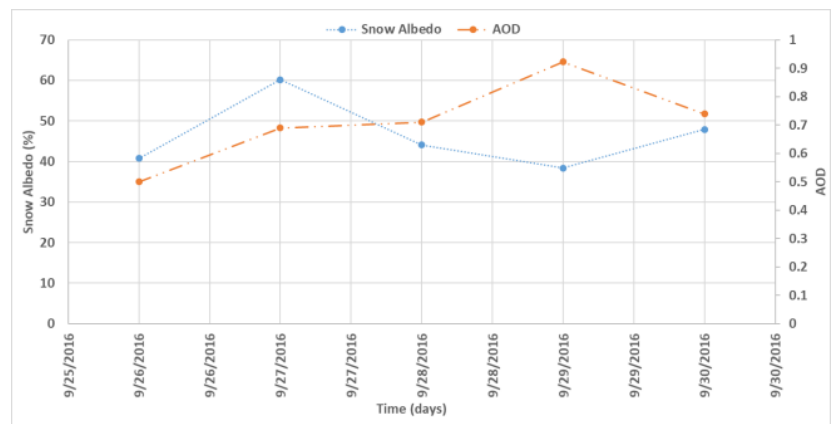

Figure 2. Daily average of snow albedo and optical depth of aerosols for pixels with $100 \%$ snow cover to each basin during 4 consecutive days in September 2016 on Tunuyán basin.

\subsubsection{WRF-Chem modelling}

To analyse the contribution of aerosol to the studied basin, we run a numerical meteorological prediction model, the Weather Research and Forecast with Chemistry (WRF-Chem) (Grell GA et al 2005). This model was used with a parametrization shown in Table 5, which was already tested in this region (Morata D et al 2008; Puliafito SE et al 2015; Mulena GC et al 2016; Cremades PG et al 2017; Bolaño-Ortiz et al 2019).

\begin{tabular}{|c|c|}
\hline Parameterization & Scheme \\
\hline \multicolumn{2}{|c|}{ Input data } \\
\hline Ground elevation & SRTM3 \\
\hline LULC & GLOBCOBER+DMPS-OLS \\
\hline Meteorology IC/BC & Re-analysis NCEP-GFS \\
\hline SST & NCEP_daily \\
\hline
\end{tabular}

\begin{tabular}{|c|c|}
\hline Parameterization & Scheme \\
\hline \multicolumn{2}{|c|}{ Chemistry } \\
\hline Gas phase & CBM-Z \\
\hline Aerosols & MOSAIC 4 bin module \\
\hline Chemistry IC/BC & MOZART-4 \\
\hline Global emissions inventory & EDGAR \\
\hline Regional Emissions Inventory & Local inventory - GEAA \\
\hline \multicolumn{2}{|c|}{ Physical } \\
\hline Microphysics & Morrison double-moment \\
\hline Cumulus & Grell Devenyi \\
\hline Long wave radiation & RRTM \\
\hline Short wave radiation & Goddard Dudhia \\
\hline Surface & Noah Land Surface Model \\
\hline PBL & YSU \\
\hline \multicolumn{2}{|c|}{ Resolution } \\
\hline Temporary & $\Delta \mathrm{t}(\mathrm{seg})=90$ \\
\hline Spatial & $\Delta \mathrm{x}, \Delta \mathrm{y}(\mathrm{km})=36,12,4$ \\
\hline Vertical & $\Delta \mathrm{z}($ ETA levels $)=50$ \\
\hline
\end{tabular}

Table 5. Details of the parameterization used in the WRF-Chem simulation

WRF-Chem model was run using three nested domains and was verified using vertical profiles of several meteorological variables for September 28 and 29, 2016. Aerosol deposition as light-absorbing particles (BC) is very efficient to decrease the snow albedo (Keegan KM et al 2014; Zhang Y et al 2017; Skiles SMK et al 2018), and we used BC to simulate and estimate the distributions over the basin of the study area (Figure. 1).

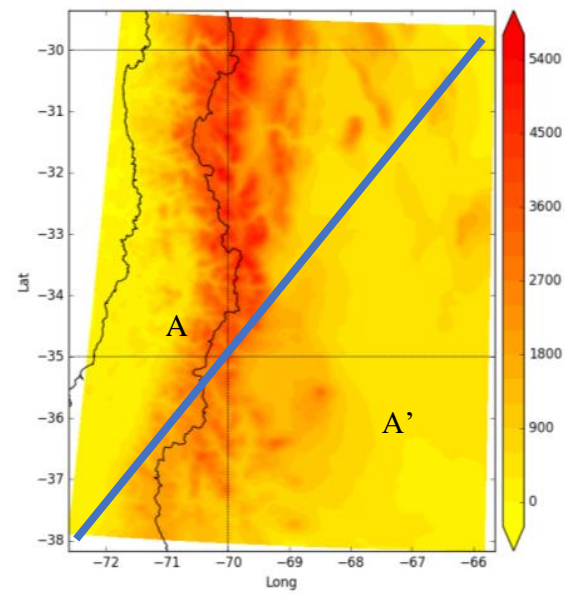

Figure 3. Terrain elevation and cross section (blue line) to observe the vertical behavior of $\mathrm{BC}$ concentrations for the Tunuyán basin (A-A') 

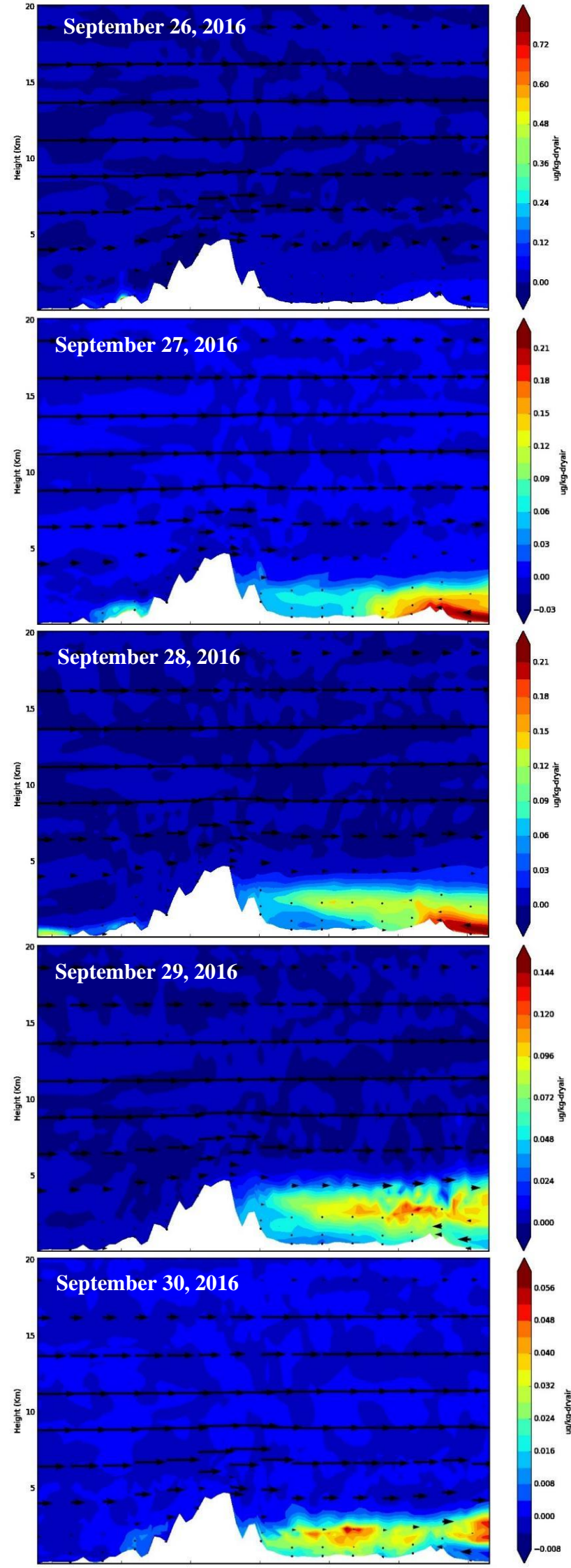

Figure 4. Vertical profile to BC average concentration for cross section A-A' shown in Figure 3 over the Tunuyán basin on September 26-30, 2016. Arrows indicate direction of zonal winds.
The snowpack in the studied area is a very important source of water supply in central Argentina because snow stores fresh water during the cold and wet season and then gradually releases water during warm season, representing an important contribution to the river flows of this region (Masiokas $\mathrm{MH}$ et al 2006; Masiokas MH et al 2016). In addition, several studies suggest that a snowpack reduction in this mountain area has impacts on the hydrological cycle and the water supply for the region (Mernild SH et al 2017; Meza FJ et al 2012). The variations and high absorbent aerosols deposited in the snow analyzed in this study suggest that the sources of anthropogenic aerosols may be playing a role in the availability of water through a positive effect with solar radiation.

NOAA HYSPLIT MODEL

Forward trajectories starting at 1100 UTC 29 Sep 16 GFSG Meteorological Data

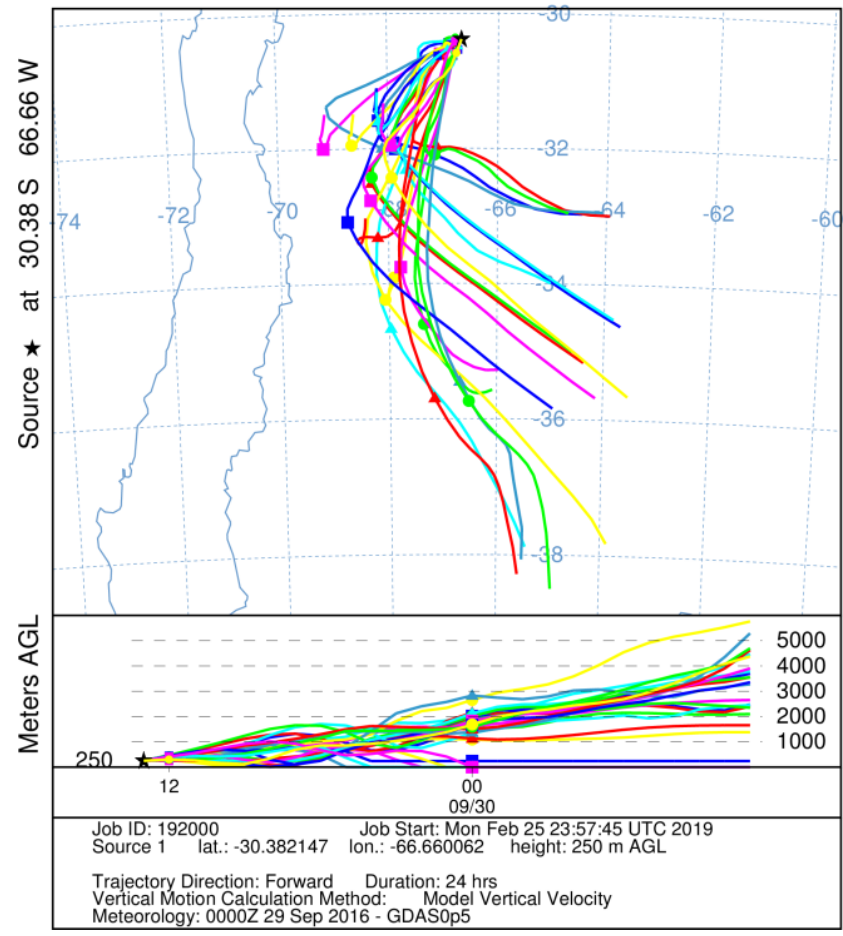

Figure 5. Trajectory from the emission source estimated for the day of higher BC antibodies on the Argentine side (September 29,2016 ) by NOAA HYSPLIT.

The differences simulations (Fire_ON - Fire_OFF) indicate BC source only by Biomass Burning, also show than from September 26 start to increase BC values over the Tunuyán basin (the eastern side of the Andes mountains) up the highest values on September 29, later start to decrease to low altitude (shown in Figure 4). This behaviour has been observed too on AOD variations to same days (Figure 2). The estimated maximum values of $\mathrm{BC}$ were explained by higher $\mathrm{AOD}$ and air mass transport patterns by the NOAA HYSPLIT model (Figure 5). The AOD peak originated from the northeast of Argentina with emission source of AOD in the areas where many biomass burning situations are present

\section{CONCLUSIONS}

Our results suggest that the decrease in SA due to AOD, in the case of study, originated due to BC generated by the burns that commonly occur at that time of year in Argentina and South 
America, which produces an impact negative in snow and hydrological resources generated in the Central Andes. In special, our case study on the Tunuyán Basin show results showed a reasonable representation of the smoke sources observed in images of the WRF-Chem output.

\section{ACKNOWLEDGEMENTS}

This work was supported by Universidad Tecnológica Nacional (UTN IFI Projects PID 1799 and 1487, CONICET (CONICET PIP 11220110100673 and PICT 2016 1115), and the authors are thankful to FCE UNCUYO for allowing to run the WRFChem model on its cluster. We also acknowledge the MODIS, SRTM DEM and NOAA HYSPLIT mission scientists and associated personnel for the production of the data used in this research effort

\section{REFERENCES}

Adler RF, Huffman GJ, Bolvin DT (2000) Tropical rainfall distributions determined using TRMM combined with other satellite and rain gauge information. J Appl Meteorol. https://doi.org/10.1175/15200450(2001)040\%3c2007:trddut\%3 e2.0.co;2

Bolaño-Ortiz TR, Allende DG, Puliafito SE, Pascual-Flores RM, Ruggeri MF (2017) Potential deposition of atmospheric aerosols on the snow and albedo reduction in the Mendoza river basin, Argentina. In: 5th iLEAPS science conference abstracts, Oxford, UK. https://doi.org/10.13140/rg.2.2.20370.09924

Bolaño-Ortiz TR, Ruggeri MF, Pascual-Flores RM, Allende DG, Lakkis SG, Puliafito SE (2018) Relationship between anthropic pollution in the Santiago Metropolitan Region and the decrease of snow albedo on the Maipo river basin, Chile. In: 2018 joint 14th iCACGP quadrennial symposium/15th IGAC science conference, Takamatsu, Japan. https://doi.org/10.13140/rg.2.2.16385.51043

Bolaño-Ortiz, T. R., Pascual-Flores, R. M., López-Noreña, A. I., Ruggeri, M. F., Lakkis, S. G., Fernández, R. P., \& Puliafito, S. E. (2019). Assessment of absorbing aerosols on austral spring snow albedo reduction by several basins in the Central Andes of Chile from daily satellite observations (2000-2016) and a case study with the WRF-Chem model. SN Applied Sciences, 1(11), 1352. https://doi.org/10.1007/s42452-019-1256-z

Cara L, Masiokas M, Viale M, Villalba R (2016) Análisis De La Cobertura Nival De La Cuenca Superior Del Río Mendoza a Partir De Imágenes Modis. Meteorológica 41:21-36. https://doi.org/10.1097/j.pain.0000000000000613

Cereceda-Balic F, Palomo-Marín MR, Bernalte E, Vidal V, Christie J, Fadic X et al (2012) Impact of Santiago de Chile urban atmospheric pollution on anthropogenic trace elements enrichment in snow precipitation at Cerro Colorado, Central Andes. Atmos Environ 47:51-57. https://doi.org/10.1016/J.ATMOSENV.2011.11.045

Cereceda-Balic F, Vidal V, Moosmüller H, Lapuerta M (2018) Reduction of snow albedo from vehicle emissions at Portillo, Chile. Cold Reg Sci Technol 146:43-52. https://doi.org/10.1016/J.COLDREGIONS.2017.11.008

Clarke AD, Noone KJ (1985) Soot in the Arctic snowpack: a cause for perturbations in radiative transfer. Atmos Environ 19(12):20452053.
Cremades PG, Fernández RP, Allende DG, Mulena GC, Puliafito SE (2017) High resolution satellite derived erodibility factors for WRF/Chem windblown dust simulations in Argentina. Atmosfera 30(1):11-25. https://doi.org/10.20937/ATM.2017.30.01.02

Flanner MG, Zender CS, Randerson JT, Rasch PJ (2007) Present-day climate forcing and response from black carbon in snow. J Geophys Res 112(D11):D11202. https://doi.org/10.1029/2006JD008003

Grell GA, Peckham SE, Schmitz R, McKeen SA, Frost G, Skamarock WC, Eder B (2005) Fully coupled "online" chemistry within the WRF model. Atmos Environ 39(37):69576975. https://doi.org/10.1016/J.ATMOSENV.2005.04.027

Griggs DJ, Noguer M (2002) Climate change 2001: the scientific basis. Contribution of working group I to the third assessment report of the intergovernmental panel on climate change. Weather 57:267-269. https://doi.org/10.1256/004316502320517344

Hall DK, Riggs GA, Salomonson VV, DiGirolamo NE, Bayr KJ (2002) MODIS snow-cover products. Remote Sens Environ 83(1-2):181-194

Hansen J, Sato M, Ruedy R (1997) Radiative forcing and climate response. Journal of Geophysical Research: Atmospheres https://doi.org/10.1029/96jd03436

Hansen JE, Sato M (2001) Trends of measured climate forcing agents. Proc Natl Acad Sci USA 98(26):14778-14783. https://doi.org/10.1073/pnas.261553698

Hong Y, Alder R, Huffman G (2006) Evaluation of the potential of NASA multi-satellite precipitation analysis in global landslide hazard assessment. Geophys Res Lett. https://doi.org/10.1029/2006g1028010

Huffman G, Bolvin D (2007b) TRMM and other data precipitation data set documentation. https://doi.org/10.1162/leon_r_00463

Huffman GJ, Bolvin DT, Nelkin EJ, Wolff DB, Adler RF, Gu G et al (2007a) The TRMM multi-satellite precipitation analysis (TMPA): quasi-global, multiyear, combined-sensor precipitation estimates at fine scales. J Hydrometeorol. https://doi.org/10.1175/jhm560.1

IPCC (2007) Climate Change 2007-the physical science basis: working group I contribution to the fourth assessment report of the IPCC. Cambridge University Press, Cambridge

Keegan KM, Albert MR, McConnell JR, Baker I (2014) Climate change and forest fires synergistically drive widespread melt events of the Greenland Ice Sheet. Proc Natl Acad Sci. https://doi.org/10.1073/pnas.1405397111

Klein AG, Barnett AC (2003) Validation of daily MODIS snow cover maps of the Upper Rio Grande River Basin for the 20002001 snow year. Remote Sens Environ 86(2):162-176. https://doi.org/10.1016/s0034-4257(03)00097-x 
Klein AG, Stroeve J (2002) Development and validation of a snow Albedo algorithm for the MODIS instrument. Ann Glaciol 34:45-52. https://doi.org/10.3189/172756402781817662

Lee W-L, Liou KN (2012) Effect of absorbing aerosols on snow albedo reduction in the Sierra Nevada. Atmos Environ 55:425430. https://doi.org/10.1016/j.atmosenv.2012.03.024

Levy R, Hsu C (2015) MODIS atmosphere L2 aerosol product. NASA MODIS adaptive processing system. Goddard Space Flight Center, Terra, Greenbelt. https://doi.org/10.5067/MODIS/MOD08_D3.006

Levy RC, Remer LA, Mattoo S, Vermote EF, Kaufman YJ (2007) Second-generation operational algorithm: retrieval of aerosol properties over land from inversion of Moderate Resolution Imaging Spectroradiometer spectral reflectance. Journal of Geophysical Research: Atmospheres. https://doi.org/10.1029/2006jd007811

Malmros JK, Mernild SH, Wilson R, Tagesson T, Fensholt R (2018) Snow cover and snow albedo changes in the central Andes of Chile and Argentina from daily MODIS observations (2000-2016). Remote Sens Environ 209(February):240-252. https://doi.org/10.1016/j.rse.2018.02.072

Masiokas MH, Christie DA, Le Quesne C, Pitte P, Ruiz L, Villalba $R$ et al (2016) Reconstructing the annual mass balance of the Echaurren Norte glacier (Central Andes, $33.5^{\circ} \mathrm{S}$ ) using local and regional hydroclimatic data. Cryosphere 10(2):927940. https://doi.org/10.5194/tc-10-927-2016

Masiokas MH, Villalba R, Luckman BH, Le Quesne C, Aravena JC (2006) Snowpack variations in the Central Andes of Argentina and Chile, 1951-2005: large-scale atmospheric influences and implications for water resources in the region. J Clim 19(24):6334-6352. https://doi.org/10.1175/JCLI3969.1

Menon S (2002) Climate effects of black carbon aerosols in China and India. Science 297(5590):2250-2253. https://doi.org/10.1126/science.1075159

Mernild SH, Liston GE, Hiemstra C, Beckerman AP, Yde JC, McPhee J (2017) The Andes Cordillera. Part IV: spatiotemporal freshwater run-off distribution to adjacent seas (19792014). Int J Climatol 37(7):3175-3196. https://doi.org/10.1002/joc.4922

Meza FJ, Wilks DS, Gurovich L, Bambach N (2012) Impacts of climate change on irrigated agriculture in the Maipo Basin, Chile: reliability of water rights and changes in the demand for irrigation. Journal of Water Resources Planning and Management https://doi.org/10.1061/(ASCE)WR.1943-5452.0000216

Morata D, Polvé M, Valdés A, Belmar M, Dinator MI, Silva M et al (2008) Characterisation of aerosol from Santiago, Chile: an integrated PIXE-SEM-EDX study. Environ Geol 56(1):81-95. https://doi.org/10.1007/s00254-007-1141-8

Mulena GC, Allende DG, Puliafito SE, Lakkis SG, Cremades PG, Ulke AG (2016) Examining the influence of meteorological simulations forced by different initial and boundary conditions in volcanic ash dispersion modelling. Atmos Res 176-177:29 42. https://doi.org/10.1016/j.atmosres.2016.02.009

Qian Y, Yasunari TJ, Doherty SJ, Flanner MG, Lau WKM, Ming $\mathbf{J}$ et al (2015) Light-absorbing particles in snow and ice: measurement and modeling of climatic and hydrological impact. Adv Atmos Sci. https://doi.org/10.1007/s00376-014-0010-0

Pepin N, Bradley RS, Diaz HF, Baraer M, Caceres EB, Forsythe $\mathrm{N}$ et al (2015) Elevation-dependent warming in mountain regions of the world. Nature Climate Change. https://doi.org/10.1038/nclimate2563

Pu Z, Xu L, Salomonson VV (2007) MODIS/Terra observed seasonal variations of snow cover over the Tibetan Plateau. Geophys Res Lett 34(6):L06706. https://doi.org/10.1029/2007GL029262

Puliafito SE, Allende DG, Mulena CG, Cremades P, Lakkis SG (2015) Evaluation of the WRF model configuration for Zonda wind events in a complex terrain. Atmos Res 166:24-32. https://doi.org/10.1016/j.atmosres.2015.06.011

Riggs GA, Hall DK, Salomonson VV (2006) MODIS snow products. User guide to collection 5. https://modissnowice.gsfc.nasa.gov/uploads/sug_c5.pdf. Accessed 25 Nov 2018

Rolph G, Stein A, Stunder B (2017) Real-time environmental applications and display system: READY. Environ Model Softw

https://doi.org/10.1016/j.envsoft.2017.06.025 95:210-228

Seemann SW, Borbas EE, Li J, Menzel WP, Gumley LE (2006) MODIS atmospheric profile retrieval algorithm theoretical basis document. Cooperative Institute for Meteorological Satellite Studies, University of Wisconsin-Madison, Madison, WI, Version

http://citeseerx.ist.psu.edu/viewdoc/download?doi=10.1.1.385.7 746\&rep=rep1\&type=pdf. Accessed 19 Nov 2018

Skiles SMK, Flanner M, Cook JM, Dumont M, Painter TH (2018) Radiative forcing by light-absorbing particles in snow. Nature Climate Change 8(11):964-971. https://doi.org/10.1038/s41558-018-0296-5

Stein AF, Draxler RR, Rolph GD, Stunder BJB, Cohen MD, Ngan F (2015) NOAA's HYSPLIT atmospheric transport and dispersion modeling system. Bull Am Meteor Soc 96(12):20592077. https://doi.org/10.1175/BAMS-D-14-00110.1

Wan Z, Li Z-L (1997) A physics-based algorithm for retrieving land-surface emissivity and temperature from EOS/MODIS data. IEEE Trans Geosci Remote Sens 35(4):980-996. Htt ps://doi.org/10.1109/36.602541

Warren SG, Wiscombe WJ (1980) A model for the spectral albedo of snow. II: snow containing atmospheric aerosols. J Atmos Sci 37(12):2734-2745. https://doi.org/10.1175/15200469(1980)037\%3c2734:amftsa\%3e2.0.co;2

Xu R, Tie X, Li G, Zhao S, Cao J, Feng T, Long X (2018) Effect of biomass burning on black carbon (BC) in South Asia and Tibetan Plateau: the analysis of WRF-Chem modeling. Sci Total Environ 645:901-912 https://doi.org/10.1016/j.scitotenv.2018.07.165

Zhang Y, Kang S, Cong Z, Schmale J, Sprenger M, Li C et al (2017) Light-absorbing impurities enhance glacier albedo reduction in the southeastern Tibetan plateau. J Geophys Res. https://doi.org/10.1002/2016jd026397 